\title{
PROMOSI DAN FASILITAS SERTA PENGARUHNYA TERHADAP KEPUTUSAN PEMBELIAN PADA PERUMAHAN PERSADA BANTEN
}

\author{
Ihwan Satria Lesmana \\ Universitas Bina Bangsa Banten \\ ihwansatrialesmana@gmail.com,
}

\author{
Abdul Bahits \\ Universitas Bina Bangsa Banten \\ Ab.bina_bangsa@yahoo.com \\ Jefran Adiswanse \\ Universitas Bina Bangsa Banten \\ jefranadiswanse1998@gmail.com
}

\begin{abstract}
Abstrak : Pemenuhan kebutuhan masyarakat akan tempat tinggal ini menjadi sangat penting, mengingat fungsi rumah yang sangat vital sebagai sarana tempat tinggal. Hal ini juga berdampak terhadap kebutuhan masyarakat Kota Serang dan sekitarnya, akan sarana perumahan. Penelitian ini bertujuan untuk mengetahui pengaruh promosi dan fasilitas terhadap keputusan pembelian pada Perumahan Persada Banten. Metode penelitian yang digunakan adalah pendekatan kuantitatif, yakni untuk mengolah data-data yang diperoleh dari lokasi penelitian. Dengan jumlah populasi sebanyak 3318 dan sampel sebanyak 97 responden dengan menggunakan persamaan slovin. Hasil pengujian hipotesis pertama $\left(\mathrm{H}_{1}\right)$ nilai signifikasi $=0,652$ lebih besar dari pada 0,05 atau nilai sig $>0,05$, maka $\mathrm{H}_{\mathrm{o}}$ diterima $\mathrm{H}_{\mathrm{a}}$ ditolak. Hasil pengujian hipotesis kedua $\left(\mathrm{H}_{2}\right)$ nilai signifikasi $=0.000$ lebih kecil dari pada 0,05 atau nilai sig $<0,05$, maka $\mathrm{H}_{\mathrm{a}}$ diterima $\mathrm{H}_{\mathrm{o}}$ ditolak. Hasil pengujian hipotesis ketiga $\left(\mathrm{H}_{3}\right) \mathrm{F}_{\text {hitung }}=16,152$ dan $\mathrm{F}_{\text {tabel }}=3,09$ jadi $\mathrm{F}_{\text {hitung }}>\mathrm{F}_{\text {tabel }}$ dengan tingkat signifikan di bawah 0,05, yaitu 0.000. Berdasarkan hasil pengujian hipotesis dapat diambil kesimpulan bahwa promosi tidak berpengaruh terhadap keputusan pembelian, dan fasilitas berpengaruh terhadap keputusan pembelian, serta secara simultan promosi dan fasilitas berpengaruh terhadap keputusan pembelian pada Perumahan Persada Banten.
\end{abstract}

Kata Kunci : Promosi, Fasilitas dan Keputusan Pembelian.

\section{PENDAHULUAN}

Saat ini, banyak masyarakat khususnya masyarakat Kota Serang yang membutuhkan sarana perumahan dengan berbagai macam fasilitas dan kemudahan untuk mendapatkannya. Berawal dari hal tersebut, banyak pengembang perumahan berlomba-lomba untuk mewujudkan kebutuhan dan keinginan masyarakat tersebut, yang salah satunya adalah PT. Harapan Inti Persada Indah. PT. Harapan Inti Persada Indah merupakan salah satu perusahaan yang bergerak di bidang property, yakni sebagai pengembang perumahan Persada Banten yang berlokasi di Kecamatan Walantaka.

Pemerintah dalam hal ini telah berupaya untuk menambah jumlah dan membangun perumahan sebanyak-banyaknya serta membuka kesempatan seluas-luasnya bagi setiap warga negara dan 
perusahaan-perusahaan swasta untuk ikut berperan dalam penyediaan perumahan dan pemukiman.

Mencermati adanya peluang bisnis ini, maka PT. Harapan Inti Persada Indah berkesempatan untuk menarik minat konsumen dalam membuat perumahan yang selama ini telah dibangun di Kota Serang. Hal ini dilakukan perusahaan dengan memperhatikan berbagai faktor yang mempengaruhi keputusan konsumen dalam pembelian rumah, diantaranya dengan mempromosikan produk perumahan, seperti harga yang bersaing, fasilitas yang memadai, pelayanan yang baik, lokasi-lokasi yang strategis dan desain yang menarik guna mencapai keputusan pembelian pada Perumahan Persada Banten.

Setiap perusahaan termasuk PT. Harapan Inti Persada Indah dalam usaha mempertahankan kelangsungan hidup perusahaan adalah merupakan hal yang sangat penting. Salah satu persoalan yang banyak dihadapi adalah berkaitan dengan pemasaran. Dalam pemasaran, bagaimana supaya barang atau jasa tersebut terjual dan memberikan rangsangan agar konsumen mau membeli, lalu mereka merasa puas dengan apa yang didapatkannya. Setiap perusahaan menganut sistem pemasaran yang berbeda tergantung kebutuhan dari perusahaan tersebut. Secara teoritik, kebijakan yang ditempuh oleh perusahaan dalam memasarkan hasil produknya dikenal dengan istilah marketing mix, terdiri atas bagaimana menciptakan produk, promosi, pelayanan yang baik dan memilih saluran distribusi.

Fasilitas yang disediakan oleh pengembang Perumahan Persada Banten yang juga dapat dibilang belum memadai, hal tersebut sangat mempengaruhi dan menjadi pertimbangan bagi calon konsumen dalam membeli rumah. Pos satpam yang seharusnya menjadi fasilitas umum di setiap perumahan tidak berdiri secara layak dan bahkan pos satpam sebagai fasilitas umum untuk pelanggan tidak pernah masuk dalam rancangan atau strategi keamanan dari perumahan tersebut. Fasilitas ruang tunggu, kamar mandi bagi konsumen ataupun pengunjung kurang memadai.

Begitu juga untuk fasilitas yang lain, seperti mencakup lebar jalan dan kondisi jalan di depan rumah yang merupakan salah satu hal yang cukup penting dan diperhatikan calon pembeli. Fasilitas keamanan lingkungan perumahan, fasilitas penunjang keamanan dan kemudahan seperti adanya area pertokoan, pusat kebugaran, arena olah raga, rekreasi, dan sebagainya juga merupakan hal dipertimbangkan. Semakin tinggi kualitas dan kuantitas fasilitas kenyamanan dan kemudahaan, maka semakin tinggi pula nilai jual perumahan. Fasilitas lain yang dipertimbangkan adalah fasilitas yang ada di dalam rumah itu sendiri, seperti jumlah kamar mandi, jumlah kamar tidur, serta ruang-ruang dan kelengkapan lain, seperti kolom renang, kolom ikan, dan sebagainya.

Promosi dan fasilitas merupakan elemen kunci dalam penawaran pasar (market offering). Untuk itu, Perencanaan bauran pemasaran harus dimulai dengan memformulasikan suatu penawaran untuk memenuhi kebutuhan atau keinginan konsumen. Faktor yang mempengaruhi keputusan kurangnya daya beli masyarakat Perumahan Persada Banten, diantaranya dengan menawarkan produk perumahan di lokasi-lokasi yang strategis, persyaratan yang tidak rumit, dan desain yang menarik.

\section{LANDASAN TEORI}

\section{Keputusan Pembelian}

Sesuatu yang dilakukan oleh konsumen pada saat membuat keputusan pembelian adalah pengenalan masalah, pencarian informasi, evaluasi alternatif, keputusan pembelian dan perilaku setelah membeli. Berdasarkan teori tersebut disimpulkan bahwa keputusan pembelian yang dilakukan adalah berdasarkan dengan apa yang telah konsumen 
pertimbangkan sesuai dengan kebutuhan dan keinginan mereka. (Wariki, Mananeke, \& Tawas, 2015)

Keputusan pembelian merupakan salah satu bagian dari perilaku konsumen yang menunjuk pada perilaku membeli konsumen akhir yang membeli barang atau jasa untuk konsumsi pribadi. Setiap hari konsumen dihadapkan pada berbagai pilihan barang atau jasa dan mengharuskan konsumen untuk memutuskan barang atau jasa apa yang akan mereka beli atau konsumsi.

Keputusan pembelian adalah bagian pokok dalam perilaku konsumen yang mengarah kepada pembelian produk barang dan jasa untuk memenuhi kebutuhan mereka baik dengan membayar atau menukarkan barang yang mereka miliki. Peningkatan keputusan pembelian barang dan jasa sangat diharapkan oleh produsen karena hal tersebut otomatis dapat meningkatkan laba perusahaan. (Tjiptono, 2015)

Pernyataan lain mengenai keputusan pembelian dalam tahap evaluasi, konsumen membuat peringkat merek dan membentuk niat untuk membeli. Pada umumnya, keputusan membeli konsumen adalah membeli merek yang paling disukai, tetapi dua faktor dapat muncul antara niat untuk membeli dan keputusan untuk membeli. Faktor pertama adalah sikap orang lain, yaitu pendapat dari orang lain mengenai harga, merek yang akan dipilih konsumen. Faktor kedua adalah faktor situasi yang tidak diharapkan, harga yang diharapkan dan manfaat produk yang diharapkan. Akan tetapi, peristiwa-peristiwa yang tak diharapkan bisa menambah niat pembelian. (Dudung, 2012)

Terdapat beberapa indikator dalam pengambilan keputusan, yaitu : (Sholihat \& Rumyeni , 2018)

a. Kemantapan pada sebuah produk, yaitu kemantapa keyakinan pelanggan dalam memilih suatu produk yang akan dibelinya.

b. Kebiasaan dalam membeli produk yaitu kebiasaan konsumen untuk membeli produk yang sama, karena produk tersebut telah sesuai dengan apa yang diharapkan.

c. Memberikan rekomendasi kepada orang lain yaitu kesediaan konsumen untuk merekomendasikan produk yang telah dirasakan kepada teman atau keluarga, baik dari segi pelayanan yang memuaskan ataupun manfaat yang didapat dari pembelian produk tersebut.

d. Melakukan pembelian ulang yaitu kesedian konsumen untuk datang dan membeli kembali produk yang telah mereka beli dan rasakan kualitasnya.

\section{Promosi}

Promosi merupakan salah satu kegiatan pemasaran yang penting bagi perusahaan dalam upaya mempertahankan kontinuitas serta meningkatkan kualitas penjualan. Untuk meningkatkan kegiatan pemasaran dalam hal memasarkan unit perumahan, menggunakan saluran distribusi dan saluran harga yang tetap, tapi juga didukung oleh kegiatan promosi. Promosi adalah aktivitas pemasaran dengan cara menyebarkan informasi, mempengaruhi, membujuk dan mengingatkan pasar sasaran agar bersedia menerima, membeli, dan loyal pada produk. Perusahaan harus mengatur strategi promosi yang tepat agar produk perusahaan bisa dikenal oleh konsumen. Dengan promosi yang tepat dengan informasi yang terkandung dalam promosi tersebut, maka konsumen akan tertarik membeli suatu produk. (Monica, 2018)

Pendapat lain bahwa promosi adalah kegiatan yang dilakukan untuk memberitahu pembeli tentang keberadaan produk di pasar atau kebijakaan pemasaran tertentu yang baru 
ditetapkan perusahaan, misalnya pemberian bonus pembelian atau pemotongan harga. (Sriyanto, 2015)

\section{Fasilitas}

Mengutip pendapat Tjiptono dalam mendefinisikan mengenai fasilitas sebagai sumber daya fisik yang harus ada sebelum suatu jasa dapat ditawarkan kepada konsumen. Fasilitas dapat pula berupa segala sesuatu yang memudahkan konsumen dalam memperoleh kepuasan karena suatu bentuk jasa tidak bisa dilihat, tidak bisa dicium dan tidak bisa diraba, maka aspek wujud fisik menjadi penting sebagai ukuran dari pelayanan. (Karim, Tumbel, \& Soepeno, 2015)

Pendapat lain mengatakan bahwa fasilitas adalah penyediaan perlengkapan-perlengkapan fisik untuk memberikan kemudahan kepada para tamu dalam melaksanakan aktivitasaktivitas atau kegiatan-kegiatannya, sehingga kebutuhan-kebutuhan tamu dapat terpenuhi. (Lempoy, Mandey, \& Loindong, 2015)

Pendapat lain menjelaskan secara sederhana yang dimaksud dengan fasilitas adalah suatu sarana fisik yang dapat memperoses suatu masukan (input) menuju keluaran (output) yang diinginkan. Fasilitas merupakan aspek penting bagi perusahaan jasa, yang biasanya peralatan yang digunakan. (Sudarwati , Kustiyah, \& Tsani, 2017)

Demikian pula bahwa fasilitas biasanya mencakup lebar jalan dan kondisi jalan di depan rumah yang merupakan salah satu hal yang cukup penting dan diperhatikan calon pembeli. Fasilitas keamanan lingkungan perumahan, fasilitas penunjang keamanan dan kemudahan seperti adanya area pertokoan, pusat kebugaran, arena olah raga, rekreasi, dan sebagainya juga merupakan hal dipertimbangkan. Semakin tinggi kualitas dan kuantitas fasilitas kenyamanan dan kemudahaan, maka semakin tinggi pula nilai jual perumahan. Fasilitas lain yang dipertimbangkan adalah fasilitas yang ada di dalam rumah itu sendiri, seperti jumlah kamar mandi, jumlah kamar tidur, serta ruang-ruang dan kelengkapan lain, seperti kolom renang, kolom ikan, dan sebagainya. (Rafika, Retnowati, \& Sutopo, 2016)

\section{METODOLOGI PENELITIAN}

\section{Tempat dan Waktu Penelitian}

Penelitian ini mengambil tempat di Perumahan Persada Banten Jalan Raya Serang KM. 85 Kec. Walantaka Kota Serang Provinsi Banten selama 4 bulan, terhitung mulai bulan April sampai dengan bulan Juli tahun 2021.

\section{Populasi dan Sampel}

Populasi dalam penelitian ini adalah konsumen Perumahan Persada Banten sebanyak 3318 orang, kemudian dilakukan proporsi sampel berdasarkan masing-masing orang yang ada di Perumahan Persada Banten yang dapat ditemui untuk diambil data untuk penelitian ini. Menurut Umar dalam N.C. Lempoy, dkk, mengungkapkan untuk menentukan ukuran sampel dari suatu populasi dalam penelitian digunakan Metode Slovin, dengan rumus: (Lempoy, Mandey, \& Loindong, 2015)

Keterangan:

$$
n=\frac{N}{1+N(e)^{2}}
$$

$\begin{array}{lll}\mathrm{n} & = & \text { Jumlah sampel } \\ \mathrm{N} & = & \text { Jumlah populasi } \\ \mathrm{e} & = & \text { Tingkat kesalahan sampel (sampling error), biasanya } 5 \%\end{array}$




$$
\begin{aligned}
& n=\frac{3318}{1+3318(0.1)^{2}} \\
& n=\frac{3318}{34,18} \\
& n=97.074 \text { dibulatkan menjadi } n=97
\end{aligned}
$$

\section{Jenis dan Sumber Data}

Data yang dikumpulkan dan dianalisis dalam rangka pengujian hipotesis pada penelitian ini adalah data primer, yaitu data yang diperoleh langsung dari lapangan atau data yang bersumber dari informasi yang diperoleh melalui kuesioner dengan para responden atau pengamatan langsung di lokasi penelitian sehubungan langsung dengan permasalahan yang ditelitidan, data sekunder, yaitu data yang didapat adalah mengenai sejarah Perumahan Persada Banten, visi, misi dan lainnya.

\section{Analisis Data}

\section{a. Regresi Linear Berganda}

Analisis ini untuk mengetahui arah hubungan antara variabel independen dengan variabel dependen, apakah masing-masing variabel independen berhubungan positif atau negatif dan untuk memprediksi nilai dari variabel dependen apabila nilai variabel independen mengalami kenaikan atau penurunan. Analisis regresi linier berganda dalam penelitian ini dilakukan untuk mengetahui pengaruh antara promosi dan fasilitas terhadap keputusan pembelian.

Analisis regresi linear berganda dapat dicari dengan menggunakan persamaan:

Keterangan:

$$
\mathbf{Y}=\boldsymbol{\alpha}+\mathbf{b}_{1} \mathbf{X}_{1}+\mathbf{b}_{2} \mathbf{X}_{2}
$$

$\begin{array}{lll}\mathrm{Y} & = & \text { Disiplin Kerja } \\ \mathrm{X}_{1} & = & \text { Motivasi } \\ \mathrm{X}_{2} & = & \text { Pengawasan } \\ \alpha & = & \text { Konstanta } \\ \mathrm{b}_{1} & = & \text { Koefisien Regresi Motivasi } \\ \mathrm{b}_{2} & = & \text { Koefisien Regresi Pengawasan }\end{array}$

b. Uji Hipotesis

Uji hipotesis adalah metode pengambilan keputusan yang didasarkan dari analisis data, baik dari percobaan yang terkontrol maupun dari observasi (tidak terkontrol). Dalam statistik, sebuah hasil bisa dikatakan signifikan secara statistik jika kejadian tersebut hampir tidak mungkin disebabkan oleh faktor yang kebetulan, sesuai dengan batas probabilitas (peluang) yang sudah ditentukan sebelumnya.

\section{1) Uji t (Uji Parsial)}

Tujuan dari uji parsial adalah untuk membuktikan apakah variabel independen secara parsial (individu) memiliki pengaruh terhadap variabel dependen. Untuk mengetahui uji-t, maka dapat dicari dengan menggunakan rumus, sebagai berikut :

$$
t=\frac{r \sqrt{n-2}}{\sqrt{1-r^{2}}}
$$

Keterangan: 
$\mathrm{t} \quad$ : Nilai t hitung

r : Koefisien Korelasi

$\mathrm{n} \quad$ : Jumlah sampel

Hasil uji lalu dibandingkan dengan t tabel, distribusi t tabel yang digunakan memiliki persamaan nilai $\mathrm{df}=\mathrm{n}-\mathrm{k}$, di mana df adalah degree of freedom yang bisa dihitung dengan $\mathrm{n}$ sebagai jumlah sampel dikurangi dengan $\mathrm{k}$ seluruh variabel yang digunakan (variabel bebas dan variabel terikat). Kriteria pengambilan keputusan uji t, sebagai berikut :

- Jika $t_{\text {hitung }}>\mathrm{t}_{\text {tabel }}$ atau sig $\mathrm{t}<0,05$, maka $\mathrm{H}_{0}$ ditolak dan $\mathrm{H}_{\mathrm{a}}$ diterima artinya ada pengaruh dan signifikan antara variabel independen terhadap variabel dependen.

- Jika $t_{\text {hitung }}<\mathrm{t}_{\text {tabel }}$ atau sig $\mathrm{t}>0,05$, maka $\mathrm{H}_{0}$ diterima dan $\mathrm{H}_{\mathrm{a}}$ ditolak artinya tidak ada pengaruh dan signifikan antara variabel independen terhadap variabel dependen.

2) Uji F (Uji Simultan)

Uji simultan atau disebut juga uji $\mathrm{F}$ dalam analisis regresi linear berganda bertujuan untuk mengetahui apakah variabel bebas secara simultan (bersamasama) berpengaruh terhadap variabel terikat. Uji $\mathrm{F}$ dapat dicari dengan menggunakan rumus:

Keterangan:

$$
\mathrm{F}=\frac{\mathrm{r}^{2} /(\mathrm{k}-1)}{\left(1-\mathrm{r}^{2}\right) /(\mathrm{n}-\mathrm{k})}
$$

$\begin{array}{lll}\mathrm{F} & = & \text { Nilai F hitung } \\ \mathrm{r} & = & \text { Koefisien korelasi } \\ \mathrm{k} & = & \text { Jumlah variabel } \\ \mathrm{n} & = & \text { Jumlah sampel }\end{array}$

Nilai $F_{\text {hitung }}$ akan dibandingkan dengan nilai $F_{\text {tabel }}$ dengan ketentuan, sebagai berikut:

1. Taraf nyata $(\mathrm{a})=1 \%, 5 \%, 10 \%$

Penelitian ini menggunakan taraf nyata $5 \%$ atau 0,05 . Di mana degree of freedom atau derajat kebebasan (df) dalam distribusi $\mathrm{F}$ ada dua, yaitu:

Df numerator $=\mathrm{dfn}=\mathrm{df}_{1}=k-1$

Df denumerator $=\mathrm{dfd}=\mathrm{df}_{2}=n-k$

a. Jika nilai sig $<0,05$, maka variabel $\mathrm{X}_{1}$ dan $\mathrm{X}_{2}$ secara simultan berpengaruh signifikan terhadap variabel $\mathrm{Y}$.

b. Jika nilai sig $>0,05$, maka variabel $X_{1}$ dan $X_{2}$ secara simultan tidak berpengaruh signifikan terhadap variabel $\mathrm{Y}$.

2. Menentukan daerah keputusan

$\mathrm{H}_{\mathrm{o}}$ : Jika $\mathrm{F}_{\text {hitung }}<\mathrm{F}_{\text {tabel }}$ artinya variabel $\mathrm{X}_{1}$ dan $\mathrm{X}_{2}$ secara simultan tidak berpengaruh signifikan terhadap variabel $\mathrm{Y}$.

$\mathrm{H}_{\mathrm{a}}$ : Jika $\mathrm{F}_{\text {hitung }}>\mathrm{F}_{\text {tabel }}$ artinya variabel $\mathrm{X}_{1}$ dan $\mathrm{X}_{2}$ secara simultan berpengaruh signifikan terhadap variabel $\mathrm{Y}$.

Kriteria pengambilan keputusan, sebagai berikut :

a. Jika $F_{\text {hitung }}>\mathrm{F}_{\text {tabel, }}$ maka $\mathrm{H}_{0}$ ditolak dan $\mathrm{H}_{\mathrm{a}}$ diterima, artinya variabel independen secara simultan berpengaruh terhadap variabel dependen.

b. Jika $F_{\text {hitung }}<\mathrm{F}_{\text {tabel}}$, maka $\mathrm{H}_{0}$ diterima dan $\mathrm{Ha}$ ditolak, artinya variabel 
independen secara simultan tidak berpengaruh terhadap variabel dependen.

\section{c. Uji Koefisien Determinasi $\left(\mathbf{R}^{2}\right)$}

Koefisien Determinasi adalah kadar kontibusi variabel bebas terhadap variabel terikat. Koefisien determinasi dilambangkan $\mathrm{R}^{2}$. Nilai ini menyatakan proporsi variasi keseluruhan dalam nilai variabel dependen yang dapat diterangkan atau diakibatkan oleh hubungan linier dengan nilai variabel independen.

Koefisien determinasi adalah angka yang menyatakan atau digunakan untuk mengetahui kontribusi atau sumbangan yang diberikan oleh sebuah variabel bebas atau lebih terhadap variabel terikat. (Siregar, 2017)

Adapun rumus yang digunakan sebagai berikut:

Keterangan:

$$
K d=r^{2} x 100 \%
$$

$\mathrm{Kd}=$ Koefisien Determinasi

$\mathrm{r} \quad=$ Koefisien Korelasi

\section{Pengujian Hipotesis}

Hipotesis dalam penelitian ini adalah, sebagai berikut:

a. Pengaruh promosi terhadap keputusan pembelian.

$\mathrm{H}_{0}: \beta_{1}=0$ : Tidak terdapat pengaruh antara variabel promosi terhadap keputusan pembelian.

$\mathrm{H}_{1}: \beta_{1} \neq 0$ : Terdapat pengaruh antara variabel promosi terhadap keputusan pembelian.

b. Pengaruh fasilitas terhadap keputusan pembelian.

$\mathrm{H}_{0}: \beta_{2}=0$ : Tidak terdapat pengaruh antara variabel fasilitas terhadap keputusan pembelian.

$\mathrm{H}_{2}: \beta_{2} \neq 0$ : Terdapat pengaruh antara variabel fasilitas terhadap keputusan pembelian.

c. Pengaruh promosi dan fasilitas secara simultan terhadap keputusan pembelian.

$\mathrm{H}_{0}: \beta_{1,2}=0$ : Tidak terdapat pengaruh antara variabel promosi dan fasilitas secara simultan terhadap keputusan pembelian.

$\mathrm{H}_{3}: \beta_{1,2} \neq 0$ : Terdapat pengaruh antara variabel promosi dan fasilitas secara simultan terhadap keputusan pembelian.

\section{HASIL PENELITIAN}

\section{Analisis Regresi Linear Berganda}

Untuk mengetahui model regresi dari promosi dan fasilitas terhadap keputusan pembelian digunakan dalam bantuan program SPSS v.25 yang menghasilkan output, sebagai berikut:

\section{Coefficients $^{a}$}

\begin{tabular}{|c|c|c|c|c|c|}
\hline & \multicolumn{2}{|c|}{ Unstandardized Coefficients } & \multirow{2}{*}{$\begin{array}{c}\text { Standardized Coefficients } \\
\text { Beta }\end{array}$} & \multirow[b]{2}{*}{ t } & \multirow[b]{2}{*}{ Sig. } \\
\hline Model & B & Std. Error & & & \\
\hline 1 (Constant) & 22,272 & 5,226 & & 4,262 &, 000 \\
\hline Promosi & 034 & 075 & 042 & ,452 & ,652 \\
\hline Fasilitas &, 531 &, 101 & ,491 & 5,241 &, 000 \\
\hline
\end{tabular}

a. Dependent Variable: Keputusan Pembelian

Sumber: SPSS v.25 (data diolah, 2021) 
Berdasarkan tabel di atas, dapat ditulis persamaan regresi, sebagai berikut:

$\mathrm{Y}=\alpha+\mathrm{b}_{1} \mathrm{X}_{1}+\mathrm{b}_{1} \mathrm{X}_{2}$

$\mathrm{Y}=22,272+0,034 \mathrm{X}_{1}+0,531 \mathrm{X}_{2}$

Sesuai dengan persamaan garis regresi yang diperoleh, maka model regresi tersebut adalah, sebagai berikut :

1. Konstanta sebesar 22,272 artinya jika promosi dan fasilitas nilainya adalah nol, maka keputusan pembelian adalah 22,272.

2. Nilai koefisien regresi variabel promosi bernilai positif 0,034 artinya jika variabel fasilitas nilainya tetap dan variabel promosi mengalami kenaikan sebesar 1 kali atau $100 \%$, maka keputusan pembelian mengalami kenaikan sebesar 0,034 atau $3,4 \%$.

3. Nilai koefisien regresi variabel fasilitas bernilai positif 0,531 . artinya jika variabel promosi nilainya tetap dan fasilitas mengalami kenaikan 1 kali atau $100 \%$, maka keputusan pembelian mengalami kenaikan sebesar 0,531 atau 53,1\%.

\section{Pengujian Hipotesis}

Pengujian hipotesis dilakukan untuk mengetahui apakah terdapat pengaruh antara variabel independen terhadap variabel dependen atau melihat taraf signifikan dari variabel tersebut. Untuk membuktikan hal tersebut di atas, dilakukan uji t (parsial) dan uji F (simultan) sesuai dengan hasil output SPSS v.25, sebagai berikut:

\section{a. Uji Parsial (Uji t)}

Uji-t bertujuan untuk mengetahui pengaruh variabel independen secara parsial (individu) terhadap variabel dependen. Uji t yang dilakukan ini sesuai dengan hasil output SPSS v.25 yang dapat dilihat pada tabel Coefficients, berikut:

\section{Coefficients $^{a}$}

\begin{tabular}{lr|r|r|r|r}
\multicolumn{2}{c}{} & Unstandardized Coefficients & Standardized Coefficients & & \multicolumn{1}{c}{ Model } \\
Model & $\mathrm{B}$ & Std. Error & Beta & \multicolumn{1}{c}{ Sig. } \\
\hline 1 (Constant) & 22,272 & 5,226 & & 4,262 &, 000 \\
\hline Promosi &, 034 &, 075 &, 042 &, 452 &, 652 \\
\hline Fasilitas &, 531 &, 101 &, 491 & 5,241 &, 000 \\
\hline
\end{tabular}

a. Dependent Variable: Keputusan Pembelian

Sumber: SPSS v.25 (data diolah, 2021)

Adapun uji parsial dalam penelitian ini terdapat dua pengujian, yaitu:

1) Pengaruh Promosi Terhadap Keputusan Pembelian

Kriteria pengambilan keputusan uji t pada penelitian ini, sebagai berikut :

- Jika thitung $>t_{\text {tabel }}$ atau sig $\mathrm{t}<0,05$, maka $\mathrm{H}_{0}$ ditolak dan $\mathrm{H}_{\mathrm{a}}$ diterima artinya ada pengaruh antara variabel promosi terhadap variabel keputusan pembelian.

- Jika $\mathrm{t}_{\text {hitung }}<\mathrm{t}_{\text {tabel }}$ atau sig $\mathrm{t}>0,05$, maka $\mathrm{H}_{0}$ diterima dan $\mathrm{H}_{\mathrm{a}}$ ditolak artinya tidak ada pengaruh antara variabel promosi terhadap variabel keputusan pembelian.

Hasil yang diperoleh menunjukkan bahwa nilai uji t untuk variabel promosi adalah sebesar 0,452. Distribusi t tabel yang digunakan memiliki persamaan nilai $\mathrm{df}=\mathrm{n}-\mathrm{k}$. Diketahui nilai sampel (n) adalah sebanyak 97 orang yang dijadikan sebagai responden dengan $\mathrm{k}$ adalah seluruh variabel yang digunakan (variabel bebas dan variabel terikat). Di mana dalam uji parsial ini adalah sebanyak 2 variabel, sehingga $\mathrm{df}=97-2=95$ dengan tingkat 
kesalahan 5\% (tingkat kepercayaan 95\% atau alpha 0,05) dan diperoleh nilai t tabel sebesar 1,985. Berdasarkan penjelasan tersebut, maka diketahui nilai $\mathrm{t}_{\text {hitung }}<\mathrm{t}_{\text {tabel, }}$, yakni $0,452<1,985$, sehingga dapat dijelaskan bahwa $\mathrm{H}_{0}$ diterima dan $\mathrm{H}_{\mathrm{a}}$ ditolak, artinya tidak ada pengaruh antara variabel promosi terhadap variabel keputusan pembelian.

\section{2) Pengaruh Fasilitas Terhadap Keputusan Pembelian}

Kriteria pengambilan keputusan uji t pada penelitian ini, sebagai berikut :

a. Jika $t_{\text {hitung }}>t_{\text {tabel }}$ atau sig $\mathrm{t}<0,05$, maka $\mathrm{H}_{0}$ ditolak dan $\mathrm{H}_{\mathrm{a}}$ diterima artinya ada pengaruh antara variabel fasilitas terhadap variabel keputusan pembelian.

b. Jika $t_{\text {hitung }}<\mathrm{t}_{\text {tabel }}$ atau sig $\mathrm{t}>0,05$, maka $\mathrm{H}_{0}$ diterima dan $\mathrm{H}_{\mathrm{a}}$ ditolak artinya tidak ada pengaruh antara variabel fasilitas terhadap variabel keputusan pembelian.

Hasil yang diperoleh menunjukkan bahwa nilai uji t untuk variabel fasilitas adalah sebesar 5,241. Distribusi t tabel yang digunakan memiliki persamaan nilai $\mathrm{df}=\mathrm{n}-\mathrm{k}$. Diketahui nilai sampel (n) adalah sebanyak 97 orang yang dijadikan sebagai responden dengan $\mathrm{k}$ adalah seluruh variabel yang digunakan (variabel bebas dan variabel terikat). Di mana dalam uji parsial ini adalah sebanyak 2 variabel, sehingga $\mathrm{df}=97-2=95$ dengan tingkat kesalahan 5\% (tingkat kepercayaan 95\% atau alpha 0,05) dan diperoleh nilai t tabel sebesar 1,985. Berdasarkan penjelasan tersebut, maka diketahui nilai $t_{\text {hitung }}>\mathrm{t}_{\text {tabel, }}$, yakni 5,241 >1,985, sehingga dapat dijelaskan bahwa $\mathrm{H}_{0}$ ditolak dan $\mathrm{H}_{\mathrm{a}}$ diterima, artinya ada pengaruh antara variabel fasilitas terhadap variabel keputusan pembelian.

\section{b. Uji Simultan (Uji F)}

Uji simultan atau disebut juga uji $\mathrm{F}$ dalam analisis regresi linear berganda pada penelitian ini bertujuan untuk mengetahui apakah variabel bebas secara simultan (bersama-sama), yakni variabel promosi dan fasilitas berpengaruh terhadap keputusan pembelian. Uji F ini bisa dilihat dari tabel ANOVA, sebagai berikut:

\section{ANOVA $^{a}$}

\begin{tabular}{l|r|r|r|c|c} 
Model & Sum of Squares & df & Mean Square & F & Sig. \\
\hline 1 Regression & 2788,829 & 2 & 1394,415 & 16,152 &, $000^{\mathrm{b}}$ \\
\hline Residual & 8114,944 & 94 & 86,329 & & \\
\hline Total & 10903,773 & 96 & & & \\
\hline
\end{tabular}

a. Dependent Variable: Keputusan Pembelian

b. Predictors: (Constant), Fasilitas, Promosi

Sumber: SPSS v.25 (data diolah, 2021)

Kriteria pengambilan keputusan, sebagai berikut:

a. Jika $F_{\text {hitung }}>\mathrm{F}_{\text {tabel }}$ atau sig $\mathrm{t}<0,05$, maka $\mathrm{H}_{0}$ ditolak dan $\mathrm{H}_{\mathrm{a}}$ diterima, artinya variabel promosi dan fasilitas secara simultan berpengaruh terhadap keputusan pembelian.

b. Jika $F_{\text {hitung }}<\mathrm{F}_{\text {tabel }}$ atau sig $\mathrm{t}>0,05$, maka $\mathrm{H}_{0}$ diterima dan Ha ditolak, artinya variabel promosi dan fasilitas secara simultan tidak berpengaruh terhadap keputusan pembelian.

Hasil yang diperoleh berdasarkan tabel ANOVA di atas, menunjukkan bahwa nilai uji $\mathrm{F}$ adalah sebesar 16,152. Distribusi $\mathrm{F}$ menggunakan taraf probabilita 
$5 \%$ atau 0,05. Di mana degree of freedom atau derajat kebebasan (df) dalam distribusi F ada dua, yaitu df numerator (pembilang) $=\mathrm{dfn}=\mathrm{df}_{1}=3-1=2$, dan df denumerator (penyebut) $=\mathrm{dfd}=\mathrm{df}_{2}=97-3=94$, sehingga diperoleh nilai $\mathrm{F}$ tabel sebesar 3,09. Oleh karena nilai $F_{\text {hitung }}>F_{\text {tabel }}(16,152>3,09)$, serta dapat dijelaskan bahwa $\mathrm{H}_{0}$ ditolak dan $\mathrm{H}_{\mathrm{a}}$ diterima, artinya dapat disimpulkan bahwa kedua variabel independen, yakni promosi dan fasilitas apabila dilakukan secara simultan (bersama-sama) dapat berpengaruh terhadap keputusan pembelian.

\section{Koefisien Determinasi}

Untuk mengetahui besarnya kontribusi variabel promosi dan fasilitas terhadap keputusan pembelian yang dinyatakan dalam persentase dapat diketahui melalui koefisien determinasi. Hal ini dapat dilihat dari model summary yang dihasilkan dengan menggunakan software SPSS v.25, sebagai berikut:

\section{Model Summary ${ }^{\text {b }}$}

\begin{tabular}{lr|r|rr|c} 
Model & $R$ & R Square & $\begin{array}{c}\text { Adjusted R } \\
\text { Square }\end{array}$ & $\begin{array}{c}\text { Std. Error of the } \\
\text { Estimate }\end{array}$ \\
\hline 1 &, $506^{\mathrm{a}}$ &, 256 &, 240 & 9,29135 \\
\hline
\end{tabular}

a. Predictors: (Constant), Fasilitas, Promosi

b. Dependent Variable: Keputusan Pembelian

Sumber: SPSS v.25 (data diolah, 2021)

Berdasarkan tabel di atas, dapat diketahui bahwa nilai koefisien $R$ Square $\left(\mathrm{R}^{2}\right)$ sebesar 0,256 . Selanjutnya digunakan perhitungan koefisien determinasi (KD) untuk mengetahui besarnya pengaruh variabel status promosi dan fasilitas terhadap keputusan pembelian.

$$
\begin{aligned}
\mathrm{KD} & =\mathrm{R}^{2} \times 100 \% \\
\mathrm{KD} & =0,506^{2} \times 100 \% \\
& =0,256 \times 100 \% \\
& =25,6 \%
\end{aligned}
$$

Hal ini dapat disimpulkan bahwa promosi dan fasilitas memberikan pengaruh dengan kontribusi sebesar 25,6\% terhadap keputusan pembelian, sedangkan sisanya 74,4\% dipengaruhi variabel lain yang tidak dibahas dalam penelitian ini, seperti harga dan lain sebagainya.

\section{KESIMPULAN}

Berdasarkan hasil analisis yang dilakukan secara simultan antara promosi dan fasilitas terhadap keputusan pembelian pada Perumahan Persada Banten, diketahui bahwa kedua variabel tersebut memiliki pengaruh yang signifikan. Tabel tersebut menunjukkan bahwa nilai uji $F$ adalah sebesar 16,152 dengan nilai $F$ tabel sebesar 3,09. Oleh karena nilai $F_{\text {hitung }}$ $>\mathrm{F}_{\text {tabel }}(16,152>3,09)$, dapat dijelaskan bahwa $\mathrm{H}_{0}$ ditolak dan $\mathrm{H}_{\mathrm{a}}$ diterima, artinya dapat disimpulkan bahwa kedua variabel independen, yakni promosi dan fasilitas apabila dilakukan secara simultan (bersama-sama) dapat berpengaruh terhadap keputusan pembelian Perumahan Persada Banten. Berdasarkan nilai koefisien $R$ Square $\left(\mathrm{R}^{2}\right)$, kontribusi keberpengaruhan kedua variabel independen tersebut adalah sebesar 0,256. Hal ini dapat disimpulkan bahwa promosi dan fasilitas memberikan pengaruh dengan kontribusi sebesar 25,6\% terhadap keputusan pembelian, sedangkan sisanya 74,4\% dipengaruhi variabel lain yang tidak dibahas dalam penelitian ini, seperti harga, lokasi, kualitas, produk, kualitas pelayanan, dan lain sebagainya. 


\section{DAFTAR PUSTAKA}

Dudung, A. (2012). Merancang Produk. Bandung: PT. Remaja Rosdakarya Offset.

Karim, B., Tumbel, A., \& Soepeno, D. (2015). Pengaruh Fasilitas, Strategi Promosi, Dan Lokasi Terhadap Keputusan Menggunakan Jasa Pada Muscle Gym Manado. Jurnal EMBA Vol.3 No.1 ISSN 2303-1174, 502-513.

Lempoy, N. C., Mandey, S., \& Loindong, S. (2015). Pengaruh Harga, Lokasi, Dan Fasilitas Terhadap Keputusan Menggunakan Jasa Taman Wisata Toar Lumimuut (Taman Eman) Sonder. Jurnal EMBA Vol.3 No.1 ISSN 2303-1174 , 1072-1083.

Monica, E. (2018). Pengaruh Harga, Lokasi, Kualitas Bangunan dan Promosi Terhadap Minat Beli Perumahan Taman Safira Bondowoso. International Journal of Social Science and Business. Volume 2, Number 3 P-ISSN : 2614-6533 E-ISSN : 2549-6409, 141-149.

Rafika, B., Retnowati, N., \& Sutopo. (2016). Analisis Pengaruh Harga, Lokasi, Dan Fasilitas Terhadap Pembelian Rumah Di Surabaya (Studi Kasus Perumahan Griya Sutorejo Asri (Surabaya). Jurnal Manajemen BRANCHMARK Volume 2 Issue 2 ISSN : 2407-8239, 78-88.

Sholihat, A., \& Rumyeni . (2018). Pengaruh Promosi Penjualan Dan Kualitas Pelayanan Terhadap Keputusan Pembelian Di Krema Koffie. JOM FISIP Vol. 5 No. 1, 1-15.

Siregar, S. (2017). Metode Penelitian Kuantitatif Dilengkapi Dengan Perbandingan Perhitungan Manual \& SPSS. Jakarta: Kencana.

Sriyanto. (2015, Agustus 06). Analisis Pengaruh Harga, Promosi, Dan Kualitas Pelayanan Terhadap Peningkatan Penjualan Tiket PT. Rosalia Indah Tour \& Travel di Palur Karanganyar. Retrieved from Institusional Repository Universitas Muhammadiyah Surakarta: http://eprints.ums.ac.id/id/eprint/36046

Sudarwati , S., Kustiyah, E., \& Tsani, A. F. (2017). Pengaruh Lokasi, Fasilitas dan Pelayanan Terhadap Keputusan Berkunjung di Taman Satwa Taru Jurug Solo. Jurnal Manajemen Bisnis Indonesia Vol 4 No 2, 238-249.

Tjiptono, F. (2015). Strategi Pemasaran Edisi 4. Yogyakarta: ANDI.

Wariki, G. M., Mananeke, L., \& Tawas, H. (2015). Pengaruh Bauran Promosi, Persepsi Harga Dan Lokasi Terhadap Keputusan Pembelian Dan Kepuasan Konsumen Pada Perumahan Tamansari Metropolitan Manado. JURNAL EMBA Vol.3 No.2 ISSN 2303$1174,1073-1085$. 